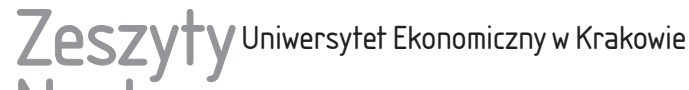 Naukowe
}

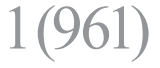

ISSN 1898-6447

Zesz. Nauk. UEK, 2017: 1 (961): 53-66 DOI: 10.15678/ZNUEK.2017.0961.0104

\section{Strategia rozwoju społeczno- -gospodarczego miasta w nowych uwarunkowaniach gospodarki światowej}

\section{Streszczenie}

Zarządzanie strategiczne miastem we współczesnych warunkach światowej gospodarki to działanie złożone, którego istotą jest szybkie reagowanie na zmiany. Wyzwania stojące przed miastami dotyczą wielu obszarów, najistotniejsze z nich związane są z inwestycjami, innowacjami, kreatywnością i konkurencyjnością. Zrównoważony rozwój pozostaje generalnym celem miasta, zmienia się jednak struktura i hierarchia celów szczegółowych. W pracach nad strategią rozwoju miasta bierze udział społeczeństwo, czego efektem ma być tworzenie miasta dopasowanego do potrzeb mieszkańców i oddziaływanie na wzrost jakości ich życia. Celem artykułu jest wskazanie uwarunkowań współczesnej gospodarki determinujących zmiany w podejściu do planowania strategicznego rozwoju społeczno-gospodarczego miast i ich priorytetów.

Słowa kluczowe: miasto, partycypacja, strategia rozwoju, globalizacja, integracja, regionalizacja.

Klasyfikacja JEL: R12, F36, O47.

Dorota Rynio, Uniwersytet Ekonomiczny we Wrocławiu, Wydział Nauk Ekonomicznych, Katedra Gospodarki Przestrzennej i Administracji Samorządowej, ul. Komandorska 118/120, 53-345 Wrocław, e-mail: dr.drynio@wp.pl 


\section{Wprowadzenie}

W gospodarce współczesnego świata dokonują się istotne zmiany priorytetów, narzędzi i podejścia do zarządzania zasobami. Szybkość przekształceń w sferze społeczno-gospodarczej, mobilności, rozwiązań techniczno-komunikacyjnych i potrzeb ludności również wpływa na kreowanie nowego obrazu miasta i jego strategicznego rozwoju. Obecnie w gospodarce światowej dochodzi do zmian w hierarchii podmiotowej, gdyż podstawowymi podmiotami odpowiedzialnymi za rozwój stają się jednostki miejskie i/lub ich połączone struktury w postaci związków miast, konurbacji, ośrodków policentrycznych. Odpowiedzialność za rozwój ponoszą te miasta, które w intensywny sposób się rozwijają (pomimo wszelkich negatywnych procesów zachodzących w gospodarce światowej). Jednocześnie w gospodarce zachodzą zmiany, które ujemnie wpływają na miasta i ich otoczenie, co prowadzić może do ich „kurczenia się”. Proces „kurczenia się” dotyczy przede wszystkim miast położonych na obszarach peryferyjnych oraz miast o monofunkcyjnej gospodarce.

W Europie proces urbanizacji przebiega w szybkim tempie. Ponad dwie trzecie ludności Europy mieszka na obszarach miejskich (do 2050 r. prognozuje się, że wskaźnik ten przekroczy 80\% [Miejski wymiar... 2014, s. 4]), co determinuje wzrost znaczenia miast w gospodarce. Ranga miast stale rośnie, stają się one lokomotywami rozwoju, ośrodkami lokowania IT, centrami usług, innowacji, kreatywności oraz miejscem spotkań. Miasta nie są już tylko odpowiedzialne za własny rozwój, ich połączenie z obszarem funkcjonalnym tworzy szerszy wymiar przestrzeni wzajemnie zależnych, a sieciowe związki miast rozszerzają zależności, przenosząc je na wyższy poziom organizacji. Stąd też ,granice administracyjne miast nie odzwierciedlają już fizycznych, społecznych, gospodarczych, kulturalnych ani środowiskowych warunków rozwoju miast i konieczne są nowe formy elastycznego zarządzania" [Miasta przyszłości... 2011, s. VI]. Dlatego też niezbędna staje się zmiana postępowania przy aktualizacji strategii miasta i tworzeniu nowego dokumentu.

Celem artykułu jest wskazanie wybranych uwarunkowań współczesnej gospodarki światowej determinujących zmiany w podejściu do planowania strategicznego rozwoju społeczno-gospodarczego miast. Jednocześnie przedstawione zostaną niektóre priorytety miast składające się na dostosowanie ich strategicznego rozwoju do wymogów gospodarki światowej, a także wytycznych Unii Europejskiej. Publikacja stanowi głos w dyskusji nad przyszłością miast. $\mathrm{W}$ opracowaniu wykorzystane zostaną metody badawcze związane $\mathrm{z}$ analizą literatury powiązanej z tematem, dedukcja, badanie poznawcze i analiza przyczynowo-skutkowa. Artykuł ma charakter sprawozdawczy, odnosi się w głównej mierze do trzech wybranych dokumentów unijnych: Nowej karty ateńskiej 
[2003], Karty lipskiej [2007], paktu amsterdamskiego [2016], oraz jednego krajowego - Krajowej polityki miejskiej (KPM) [2015]. Zawężenie rozważań do tych dokumentów jest podyktowane m.in. ograniczeniami dotyczącymi rozmiarów publikacji.

Koncepcja pracy odnosi się do zjawisk i procesów determinujących współczesny sposób planowania strategicznego na poziomie miast, który w znacznym stopniu się zmienia i uelastycznia. Sztywne ramy strategii rozwoju społeczno-gospodarczego rozpadają się, a szczegółowość zapisów ewoluuje w kierunku określania priorytetów, założeń i długookresowych wytycznych, które zawierać mają efekty najważniejszych procesów gospodarczych zachodzących w gospodarce światowej.

\section{Procesy gospodarki światowej determinujące zmiany w podejściu do zarządzania strategicznego w mieście}

Najważniejszym procesem zachodzącym we współczesnej gospodarce światowej jest globalizacja, która jest szeroko i różnie definiowana (więcej na ten temat zob. [Rynio 2013, s. 17-19]). W odniesieniu do zarządzania strategicznego miastem istotnym aspektem globalizacji jest jej wpływ na przestrzenną lokalizację działalności gospodarczej [Jewtuchowicz 2006, s. 168-169], która koncentruje się głównie w miejscach charakteryzujących się intensywnym rozwojem i tych oferujących konkurencyjne warunki lokacji kapitału. W procesie globalizacji gospodarki narodowe wiążą się ze sobą, a poszczególne rynki integrują się w zróżnicowanych przekrojach [Oman 2002, s. 35-65]. Poszerzanie i pogłębianie systemowych współzależności między różnymi szczeblami skutkuje powstaniem jakościowo nowych powiązań na niejednolitym poziomie oraz integracją gospodarki światowej [Pietrzyk 2009, s. 22]. Globalizacja to proces złożony o zróżnicowanym zasięgu, wzmacnia oddziaływanie na rynek, wpływy i zależności, kreuje sieci współpracy, koncentruje się na konkurencji. Odnotowuje się także powiązanie procesu globalizacji z wykorzystaniem nowoczesnych technik, transportu i komunikacji, co wraz z otwieraniem rynków i przepływów przyczynia się do wzrostu efektywności ekonomicznej oraz intensywnego rozwoju poszczególnych obszarów [Lubbe 2010, s. 61]. Na tle tak pojmowanej globalizacji rośnie znaczenie ośrodków miejskich sieciowo połączonych, które zyskują rangę centrów rozwoju, kreatywności i innowacyjności. Przed zarządzaniem strategicznym miastem w tych warunkach pojawiają się nowe wyzwania, szczególnie w odniesieniu do współpracy z otoczeniem bliższym i dalszym.

Integracja europejska wyznacza miastom istotną rolę w działaniach na rzecz zrównoważonego rozwoju wspólnej przestrzeni. Zdaniem J. Tinbergena [1965, 
s. 57-60] integracja koncentruje się na tworzeniu struktury gospodarki najbardziej pożądanej dla danego obszaru, gdzie w celu optymalizacji realizacji działań usuwa się sztuczne bariery, w których miejsce implementuje się pożądane elementy kooperacji i unifikacji. Integracja europejska dotyczy zróżnicowanych narodów i regionów, które podlegają procesowi scalania. Ugrupowanie takie staje się ciągle zmieniającym się podmiotem, który rozwija się dzięki szybkiej absorpcji nowości technicznych i technologicznych oraz realizacji własnych celów jednocześnie na trzech płaszczyznach: narodowej, regionalnej i globalnej. Wspólnymi celami zintegrowanych państw jest dążenie do harmonijnego rozwoju gospodarki, zmniejszanie różnic rozwojowych między regionami oraz likwidacja opóźnień w rozwoju regionów mniej uprzywilejowanych. Miasta podobnie jak w procesie globalizacji zyskują rangę centrów zogniskowanego rozwoju, przez co poświęca się tym podmiotom wiele uwagi.

Regionalizacja to proces powiązany z globalizacją i integracją. Proces ten z jednej strony wiąże się z nimi w trójkąt procesowy gospodarki światowej, $\mathrm{z}$ drugiej strony są to procesy wzajemnie przeciwstawne. Regionalizacja stanowi ważne ogniwo tych procesów, pełniące funkcje akceleratora, katalizatora i/lub pośrednika. Regionalizm może być postrzegany jako izolowanie się bądź pewien rodzaj zachowań autarkicznych, co w konsekwencji wpływa negatywnie na możliwości rozwojowe (zob. [Bauman 2000, s. 7]). Takie postępowanie ma miejsce rzadko, gdy regiony w obawie przed negatywnymi konsekwencjami globalizacji i integracji podejmują próbę oddzielenia się od tych procesów. W praktyce podstawą regionalizmu jest pogłębianie sieci wewnętrznych powiązań z jednoczesnym otwarciem się na wymianę z otoczeniem, co pozwala osiągnąć efekty synergiczne rozwoju. Z. Chojnicki i T. Czyż definiują proces regionalizacji przez wskazanie różnicowania się przestrzeni kraju, która prowadzi do wydzielania odrębnych części, mniejszych niż powierzchnia państwa, co jest konsekwencją transformacji społeczno-gospodarczej ([Chojnicki i Czyż 1993], za: [Dziemianowicz 2001, s. 83]). I. Pietrzyk zwraca uwagę na różnice między pojęciami regionalizacji i regionalizmu. Regionalizacja to samorzutne pogłębianie regionalnej integracji w ramach powiązań ekonomicznych między pobliskimi krajami, zaś regionalizm to regionalna integracja gospodarcza, której przejawem stają się inicjatywy instytucjonalne [Pietrzyk 2009, s. 31].

W warunkach współistnienia i sprzeczności podstawowych procesów zachodzących w gospodarce światowej tworzenie czy aktualizacja strategii rozwoju społeczno-gospodarczego miasta sprowadza się do balansowania na krawędziach tych procesów, a celem tego postępowania ma być realizacja idei nowoczesnego miasta, inteligentnego i kreatywnego, które ma możliwości podnoszenia swojej pozycji konkurencyjnej oraz rozwoju. Globalizacja, integracja i regionalizacja to procesy zmieniające charakter i ukierunkowanie rozwoju miast, szczególnie tych, 
które tworzą ogniska wzrostu gospodarki światowej. Otwieranie granic, w tym miejskich, rozszerzony zakres oddziaływania miast oraz ich sieciowe powiązania wpływają na podstawy dyrektyw unijnych tworzonych w zakresie gospodarowania przestrzenią, gospodarki miejskiej i zrównoważonego rozwoju. Wytyczne dokumentów i zawarte w nich priorytety stanowią o potrzebie nowego otwarcia dla polityki miejskiej, nie tylko na poziomie UE, ale także w odniesieniu do rozwiązań krajowych.

\section{Ukierunkowania długookresowego rozwoju społeczno- -gospodarczego miast Unii Europejskiej}

Programowanie strategiczne rozwoju społeczno-gospodarczego miast w warunkach globalizacji, integracji i regionalizacji z jednej strony podlega tym procesom i jest od nich zależne, $\mathrm{z}$ drugiej strony wzrost rangi miast stawia je na pozycji inicjatora zmian oraz kreatywnego podmiotu realizującego własne cele, które nie są sprzeczne z kierunkami rozwoju gospodarki światowej. UE wielokrotnie zajmowała stanowisko w sprawie potencjalnego kształtu polityki miejskiej, podejmując próbę dopasowania działań realizowanych na tym poziomie do wyzwań globalnych i nadając im wspólny kierunek. Karta ateńska [Nowa karta... 2003] odnosi się do wizji przyszłości miast europejskich. Miasta, zgodnie z zapisami dokumentu, to jednostki przestrzenne: sieciowo i funkcjonalnie połączone, bogate i zróżnicowane kulturowo, łączące teraźniejszość i przyszłość z przeszłością, twórcze, konkurencyjne, jednocześnie ze sobą współpracujące i wzajemnie się uzupełniające, dbające o dobrobyt i wygodne życie mieszkańców, łączące środowisko zurbanizowane ze środowiskiem przyrodniczym [Nowa karta... 2003, s. III]. Podstawowym dążeniem miast w XXI w. ma być spójność, dobre zarządzanie, ciągłość historyczna i fizyczna, uczestnictwo w policentrycznych sieciach miast ponad granicami państw. W efekcie oddziaływania na spójność i tworzenia połączeń powinna powstać sieciowa struktura powiązań między miastami Europy [Nowa karta... 2003, s. III]. Spójne miasto w XXI w. ma zaspokajać potrzeby całości społeczeństwa, angażować społeczeństwo w zarządzanie, realizować projekty i zgłaszane inicjatywy, gwarantować prawa i obowiązki różnych grup społecznych, a także uwzględniać wymagania poszczególnych obywateli. Wyzwaniem dla miast XXI w., zawartym w dokumencie, jest wielokulturowość i wielojęzyczność społeczności wynikająca z ruchów migracyjnych. Przyczyni się to $\mathrm{z}$ jednej strony do zapewnienia bogactwa i różnorodności cywilizacyjnej, z drugiej strony do powstania wielu problemów na rynku pracy związanych z tolerancją i wykluczeniem. Różnorodność kulturowa, językowa i religijna wymagać będzie rozwiązania narastających konfliktów oraz dojścia 
do konsensusu przy uwzględnieniu tożsamości społecznej i jednoczesnym zarządzaniu strategicznym prowadzącym do tworzenia powiązań z miastem. $\mathrm{W}$ dokumencie zwrócono uwagę na problem zmian w strukturze demograficznej miast XXI w. i dysproporcji między poszczególnymi grupami wieku. Planowanie strategiczne rozwoju społeczno-gospodarczego w mieście powinno uwzględniać konieczność wprowadzenia spójności i połączeń między różnymi grupami wieku oraz możliwości ruchowych - w zakresie socjalnym, ekonomicznym, odpowiedniej sieci usług i infrastruktury miejskiej. Dotyczy to także przestrzeni i obiektów publicznych, które powinny zapewniać: jakość lokalizacji, użytkowanie i wyposażenie odpowiadające potrzebom wszystkich grup ludzi, ich aktywizację oraz związki międzypokoleniowe. Karta ateńska zawiera również wytyczne dotyczące konieczności osiągania priorytetu sprawności miasta wraz $\mathrm{z}$ jego zapleczem funkcjonalnym w zakresie możliwości przemieszczania się różnymi środkami transportu zbiorowego, intermodalności komunikacji oraz efektywnych połączeń zewnętrznych wykorzystujących europejską sieć transportu, co będzie miało przełożenie na ograniczenie liczby pojazdów prywatnych na drogach. Programowanie strategiczne w mieście, zgodnie z zapisami dokumentu, ma prowadzić do realizacji potrzeb mieszkańców związanych z dostępem do mieszkań i usług (edukacji, handlu, obiektów kultury i wypoczynku). Istotnym elementem programowania strategicznego jest dążenie do spójności gospodarczej i środowiskowej. Dążenie do spójności ekonomicznej miasta europejskie XXI w. realizują w drodze połączeń sieciowych; szczególnie istotne staje się sieciowe powiązanie miast i ich współpraca z obszarem funkcjonalnym, co ma prowadzić do zwiększenia specjalizacji i różnorodności tych jednostek terytorialnych oraz wypracowania przewag konkurencyjnych w gospodarce globalnej. Efektem tych działań ma być również wysoki poziom zatrudnienia, specjalizacja i elastyczne dostosowywanie się do zmian w gospodarce globalnej. Spójność środowiskowa to istotny element strategii zrównoważonego miasta. W karcie ateńskiej z 2003 r. oddziaływanie na środowisko rozumiane jest nie tylko jako zachowanie i powiększanie udziału terenów zielonych w miastach i na ich obrzeżach, ale także: roztropne i oszczędne korzystanie z zasobów, samowystarczalność, odzyskiwanie oraz wtórne wykorzystanie większości zużywanych zasobów naturalnych, ochrona miast przed zanieczyszczeniami i degradacją walorów środowiska oraz zwiększenie wykorzystania energii pierwotnej. Zrównoważony rozwój miasta uzupełnia odpowiedzialne planowanie przestrzenne tworzące sieć powiązań funkcjonalnych wewnątrz miasta i miasta $\mathrm{z}$ otoczeniem.

Karta lipska określa główny cel programowania strategicznego rozwoju miast europejskich: „Europa potrzebuje silnych miast i regionów, w których dobrze się żyje" [2007, s. 9]. Osiągnięcie celu głównego związane jest z dwoma zaleceniami, wspartymi szczegółowymi wytycznymi [2007, s. 2-8]: 
1) wykorzystanie na większą skalę zintegrowanego podejścia do polityki rozwoju miejskiego:

a) tworzenie i zapewnianie przestrzeni publicznych wysokiej jakości,

b) modernizacja sieci infrastruktury i poprawa wydajności energetycznej,

c) aktywna polityka innowacyjna i edukacyjna;

2) zwrócenie szczególnej uwagi na najuboższe dzielnice w kontekście miasta jako całości:

a) realizacja strategii podnoszenia jakości środowiska fizycznego,

b) wzmocnienie gospodarki lokalnej i lokalnej polityki rynku pracy,

c) aktywna polityka edukacji i szkoleń dla dzieci i młodzieży,

d) promowanie sprawnego i korzystnego cenowo transportu miejskiego.

Duże znaczenie z punktu widzenia osiągania celów Karty lipskiej ma poziom krajowy kształtowania polityki miejskiej. Założenia poszczególnych sektorowych resortów rządowych w zakresie zagadnień miejskich dotyczą lepszej koordynacji i integracji, wzajemnego uzupełniania się, uruchomiania synergicznych innowacyjnych rozwiązań, wzmacniania podstaw finansowych polityki miejskiej wspartej funduszami europejskimi i środkami prywatnymi. Istotne jest także lokalne podejście do rozwoju miast ze względu na bezpośredniość odpowiedzialności za powodzenie strategii miejskiej.

W dniu 30 maja 2016 r. został podpisany pakt amsterdamski, w którym przedstawiono zasady wprowadzania unijnego programu rozwoju miast (agendy miejskiej UE). W dokumencie zawarto wytyczne polityki UE wobec miast, ich systemu zarządzania i monitorowania. W wyniku zastosowania wskazówek paktu amsterdamskiego ma nastąpić wzrost znaczenia miast w gospodarce regionalnej, krajowej i globalnej. W pakcie amsterdamskim zawarto trzy podstawowe cele polityki miejskiej UE: dążenie do wzmocnienia procesu legislacyjnego i współpracy środowisk miejskich przy tworzeniu prawa dotyczącego miast, efektywne finansowanie inwestycji prowadzonych $\mathrm{w}$ miastach, uproszczone procedury wsparcia środkami europejskimi i zintegrowanie narzędzi finansowych skierowanych do miast oraz zarządzanie oparte na wiedzy, ponieważ informacja jest podstawą podejmowania decyzji w mieście [Urban Agenda... 2016]. Pakt amsterdamski odnosi się do wielu aspektów funkcjonowania miasta, zakładając: skonsolidowany model zarządzania miastami ponad podziałami administracyjnymi oraz terytorialnymi, niwelowanie problemów miast w drodze partnerstwa z pozostałymi podmiotami miejskimi i ponadlokalnymi, inteligentne rozwiązania w miastach oraz funkcje przypisane miastom (platformy procesu demokratycznego, dialogu kulturowego i różnorodności kulturowej) [Pakt amsterdamski... 2016]. Partnerstwa zawierane są dobrowolnie, oddolnie i są planowane. Wskazano 12 partnerstw tematycznych, które mają służyć realizacji priorytetów UE, krajowej polityce miejskiej i sprawnemu przebiegowi programu rozwoju miast 
na wszystkich szczeblach: integracja migrantów i uchodźców, jakość powietrza, mieszkalnictwo oraz ubóstwo miejskie, gospodarka o obiegu zamkniętym, dostosowanie do zmian klimatycznych, przemiany energetyczne, mobilność miejska, technologie cyfrowe, zamówienia publiczne, miejski rynek pracy oraz zrównoważone użytkowanie gruntów i rozwiązania oparte na środowisku naturalnym [Pakt amsterdamski... 2016].

Miasta zgodnie z zapisami dokumentu mają nadal dążyć do zrównoważonego rozwoju przez realizację partnerstw. Podmioty te, wdrażając wszystkie założenia, mają również za zadanie zaspokoić zwiększone potrzeby mieszkańców i użytkowników zewnętrznych, jednocześnie zapewnić podstawy efektywnego rozwoju gospodarczego, który staje się warunkiem podniesienia jakości życia w tej przestrzeni i dobrobytu. Sprzyjać temu ma także zachowanie spójności przedsięwzięć, priorytetów i celów określanych w zróżnicowanych przekrojach terytorialnych (unijnym, krajowym i lokalnym).

Unia Europejska to ugrupowanie, które stara się kształtować miasta i ich rozwój. Współczesne problemy gospodarki światowej i jej pozytywne aspekty są podkreślane w dokumentach strategicznych. Jednocześnie istnieje konieczność efektywnego wprowadzania ustaleń do rzeczywistości krajowej, regionalnej i lokalnej wskazanych priorytetów oraz celów.

\section{Krajowe wytyczne polityki miejskiej}

Wytyczne polityki miejskiej w Polsce zawarte zostały w dokumencie Krajowa polityka miejska 2023 [2015], który dotyczy wszystkich miast i ich obszarów funkcjonalnych. Strategia rozwoju miasta, zgodnie z tym dokumentem, powinna zostać oparta na indywidualizacji stosowanych instrumentów, elastyczności ich wykorzystania, samodzielności jednostek miejskich i samorządu terytorialnego. W dokumencie określono również preferowane przez rząd kierunki rozwoju miast wraz $\mathrm{z}$ ich otoczeniem funkcjonalnym oraz podstawę rozwoju upatrywaną w zintegrowanym podejściu terytorialnym. Terytorialne ukierunkowanie odnosi się do zasobów wewnętrznych i lokalnych, które stanowią podstawę rozwoju. Wizja miast polskich zawarta w dokumencie KPM 2023 wyznacza szybki trend rozwojowy dla jednostek miejskich, które mają stać się przyjazne dla mieszkańców i przedsiębiorców, oferować wysoką jakość życia, przemyślany układ przestrzeni publicznych i atrakcyjne warunki lokowania i prowadzenia biznesu, wykazywać się nowoczesnym i długookresowym rozwojem, konkurencyjnością (szczególnie największe ośrodki mają realizować ścieżkę konkurencyjności europejskiej), charakteryzować się sieciowością współpracy na wszystkich poziomach oraz spójnością społeczną, ekonomiczną i przestrzenną. W wizji podkreślono 
również potrzebę ukierunkowania miast na ich otwartość i dostępność, sprawność i partnerstwo w zarządzaniu, wdrażanie dyrektyw środowiskowych i przygotowanie się do skutków zmian klimatu [Krajowa polityka... 2015, s. 11]. W bezpośredniej relacji z wizją miast pozostaje cel strategiczny polityki miejskiej, która ma dążyć do podniesienia zdolności miast i obszarów zurbanizowanych do zrównoważonego rozwoju, zapewniać tworzenie miejsc pracy oraz poprawę jakości życia mieszkańców [Krajowa polityka... 2015]. Cele szczegółowe polityki miejskiej to [Krajowa polityka... 2015, s. 12]:

„1) stworzenie warunków dla skutecznego, efektywnego i partnerskiego zarządzania rozwojem na obszarach miejskich, w tym w szczególności na obszarach metropolitalnych,

2) wspieranie zrównoważonego rozwoju ośrodków miejskich, w tym przeciwdziałanie negatywnym zjawiskom niekontrolowanej suburbanizacji,

3) odbudowa zdolności do rozwoju poprzez rewitalizację zdegradowanych społecznie, ekonomicznie i fizycznie obszarów miejskich,

4) poprawa konkurencyjności i zdolności głównych ośrodków miejskich do kreowania rozwoju, wzrostu i zatrudnienia,

5) wspomaganie rozwoju subregionalnych i lokalnych ośrodków miejskich, przede wszystkim na obszarach problemowych polityki regionalnej (w tym na niektórych obszarach wiejskich) poprzez wzmacnianie ich funkcji oraz przeciwdziałanie ich upadkowi ekonomicznemu".

W wyniku osiągania celów polityki miejskiej miasta w Polsce mają być: sprawne, zwarte i zrównoważone, spójne, konkurencyjne i silne, a strategie rozwoju społeczno-gospodarczego powinny uwzględniać priorytety KPM.

KPM preferuje ideę miasta zwartego, co oznacza:

- zrównoważone inwestowanie w miastach z naciskiem na obszary wcześniej zagospodarowane,

- wspieranie procesu kompleksowej rewitalizacji miast,

- wykorzystanie wolnych przestrzeni miasta lub ponowne ich zagospodarowanie, co przyciąga inwestycje i ludzi oraz pozwala na rozwój dostosowany do nowych warunków,

- wzmacnianie połączeń z otoczeniem bliższym i dalszym.

KPM 2023 wyznacza ogólne ramy programowania strategicznego w miastach, ustalając kierunek rozwoju tych jednostek przestrzennych w długim okresie. W trakcie opracowywania strategii bądź jej aktualizacji należy pamiętać o wielowątkowości i wielopoziomowości oraz wskazaniu zogniskowanych sieciowych powiązań. 


\section{Wytyczne strategii rozwoju społeczno-gospodarczego miasta w zmiennych warunkach gospodarczych}

Miasta XXI w. stoją przed wieloma wyzwaniami. Zewnętrzny wpływ na działanie miast mają:

- zmiany globalne,

- polityczne sojusze,

- światowe turbulencje gospodarcze,

- sieciowe łączenie miast i przekształcenia w podejściu do gospodarowania przestrzenią,

- negatywne zmiany klimatyczne na świecie.

Miasta wobec wyzwań i rosnących zagrożeń zmieniają model rozwoju społeczno-gospodarczego i koncepcję przestrzennego zagospodarowania. Nowe podejście do modelu rozwoju miasta w odniesieniu do sposobu zarządzania jednostką terytorialną obejmuje:

- koncepcję wielopoziomowego administrowania,

- zarządzanie ośrodkami metropolitalnymi w odniesieniu do problematyki aktywizacji zasobów miastotwórczych,

- zarządzanie obszarami funkcjonalnymi,

- racjonalne korzystanie z zasobów, w tym środowiskowych, koncentrację na alternatywnych źródłach energii.

Koncepcja miasta XXI w. opiera się na idei inteligentnego, zrównoważonego rozwoju społeczno-gospodarczego, związanego z inkluzją społeczną [Europa... 2010].

Elementy strategii miasta w zmiennych warunkach światowej gospodarki pozostają niezmienne, co oznacza, że struktura dokumentu również zachowuje swoją aktualność. Zmienność wymusza jednak elastyczność w konstruowaniu strategii. Jak w każdym tego typu dokumencie konstrukcja obejmuje: diagnozę prospektywną, wizję i/lub misję, drzewo celów strategicznych i/lub priorytety, horyzont czasu, monitoring i ewaluację, kontrolę. Często w opracowaniu strategii wykorzystuje się analizę SWOT i/lub PEST oraz macierz zadaniową. W światowej gospodarce w istotny sposób zmieniają się aparat narzędziowy strategii, metody dochodzenia do wyznaczenia celów i zakres zadań, jakie miasta uznają za niezbędne do realizacji. Decydujące będą też wyzwania globalnej gospodarki, integracyjne i regionalne. Intensywny rozwój technologii i komunikacji, innowacje i kreatywne zachowania wpływają również na kierunki rozwoju społeczno-gospodarczego ujęte w tworzonych strategiach. Strategia rozwoju to dokument opracowywany co najmniej na średni okres, częściej dotyczy zaś długiego okresu, stąd istotny staje się problem przyszłości miast w globalnej gospodarce. Miasta „są istotnymi siłami napędowymi gospodarki, będąc miejscami spotkań, 
kreatywności i innowacji oraz ośrodkami usług świadczonych na rzecz otaczających je obszarów" i będzie tak również w przyszłości [Miasta przyszłości... 2011]. W obecnych warunkach w strategii podkreśla się unikatowość ośrodka miejskiego w zakresie wartości kulturowych i architektonicznych, silnych mechanizmów integracji społecznej oraz oryginalnych możliwości rozwoju gospodarczego, jego funkcje jako centrum wiedzy oraz lokomotywy wzrostu i innowacji. Strategia rozwoju miasta powinna wskazywać sposób rozwiązania problemów, z którymi borykają się miasta w nowych uwarunkowaniach. Mimo że wewnętrzne problemy miast europejskich są zróżnicowane, część z nich dotyczy większości miast lub wykazują one regionalnie podobieństwa. Konsekwencje problemów są wewnętrzne, jednocześnie mają one skutki zewnętrzne wspólne dla sieciowo połączonych miast, tak jak w przypadku:

- intensywnej i niekontrolowanej urbanizacji oraz napływu ludności,

- tradycji i zwyczajów nowych mieszkańców miasta,

- wielokulturowości, którą należy uwzględnić przy programowaniu rozwoju,

- odpowiedzialności środowiskowej w układzie horyzontalnym i długim okresie.

Problemy miast wspólne dla większych przestrzeni, które powinny zostać uwzględnione w nowym podejściu strategicznym, to także: starzenie się ludności, zmiana priorytetów odbiorców usług miasta, niedopasowanie sektora usług i produkcji do wymogów światowej gospodarki, zmniejszające się zasoby naturalne, ograniczanie roli tradycyjnego przemysłu, rosnące zarówno pod względem ilości, jak i jakości potrzeby użytkowników miasta oraz niewystarczająco silna pozycja konkurencyjna.

Jedną z podstaw tworzenia i aktualizacji strategii rozwoju miasta jest dążenie do partnerstwa i współuczestnictwa w zarządzaniu zróżnicowanych grup użytkowników. Partycypacja dotyczy w szczególności mieszkańców miasta, którzy w sposób bezpośredni i pośredni, sformalizowany i niesformalizowany, indywidualnie i wspólnie uczestniczyć będą w procesie podejmowania decyzji, które będą mieć wpływ na jakość życia w mieście, realizację potrzeb ludności oraz rozwój tego obszaru [Olech i Kaźmierczak 2011, s. 100-112]. Uczestnictwo mieszkańców w zarządzaniu strategicznym miastem polega na przyjęciu przez nich aktywnej postawy, braniu udziału w tworzeniu lub aktualizacji strategii, decyzjach planistycznych, procesie rewitalizacji oraz sieciach obywatelskiego zaangażowania (szerzej zob. [Lariusz 2013, s. 26-27; Putnam 1995, s. 258]). Wpływa to na jakość funkcjonowania miasta w wielu aspektach. Przynosi oszczędności czasu i finansowe, wzmacnia związek społeczeństwa z miastem i odpowiedzialność za nie, pobudza kreatywny i innowacyjny rozwój miasta, przyczynia się do efektywnego wykorzystania zasobów, indywidualizuje miasto, wspiera realizację rzeczywistych potrzeb mieszkańców oraz tworzy ofertę ośrodka miejskiego 
szczególnie dopasowaną do wymagań wewnętrznych użytkowników i częściowo dostosowaną do wymogów zewnętrznych interesariuszy. Konsekwencją partycypacji społecznej we współdecydowaniu, opracowywaniu i aktualizacji strategii rozwoju społeczno-gospodarczego miasta jest często zmiana priorytetów, celów i wizji miasta, a także narzędzi, którymi posługują się władze miasta w trakcie procesu twórczego stanowienia dokumentu, jak i realizacji zapisów opracowania. Aparat narzędziowy ewoluuje w wyniku zmian technicznych, koncepcji oraz pod wpływem udziału społeczeństwa.

\section{Wnioski}

W zmiennych warunkach światowej gospodarki zarządzanie strategiczne miastami to złożony problem. Tworzenie i aktualizacja strategii wiążą się z uwzględnieniem wielu nowych lub zmienionych aspektów programowania i podejścia do gospodarki miasta. Wzmacnianie struktury miejskiej, jej zwartości oraz powiązań z obszarami funkcjonalnymi to jedne z podstawowych wytycznych do prac nad strategią rozwoju społeczno-gospodarczego, przy czym dążenie do zrównoważonego rozwoju pozostaje nadal generalnym celem wszelkich realizowanych działań. Europejskie miasta przyszłości, zgodnie z opracowaną wizją, to: „miejsca zaawansowanego postępu społecznego z wysokim poziomem spójności społecznej, społecznie zrównoważonym mieszkalnictwem, usługami socjalnymi i zdrowotnymi oraz ogólnodostępnym szkolnictwem; platformy procesu demokratycznego, dialogu kulturowego i różnorodności kulturowej; miejsca rewitalizacji przyrodniczej, ekologicznej i środowiskowej; miejsca atrakcji i lokomotywy wzrostu gospodarczego" [Miasta przyszłości... 2011, s. VI].

Na obecnym etapie rozwoju miasta powinny uwzględniać potrzeby mieszkańców, szczególnie wynikające z wizji, gdyż ich realizacja to proces długookresowy. Sformułowana wizja prezentuje wieloaspektowe i wielozadaniowe podejście do przyszłości miast, koncentrując się na tworzeniu podstaw rozwoju oraz efektywnym wykorzystaniu dostępnych zasobów, nie zawsze w konwencjonalny sposób, by uzyskać przewagę konkurencyjną.

Wzajemne przenikanie się procesów globalizacji, integracji i regionalizacji stwarza warunki, w których miasta odgrywają kluczową rolę w rozwoju terytorialnym. Dlatego zarządzanie strategiczne w tych jednostkach powinno charakteryzować elastyczne podejście do zadaniowości i problemów, a także metod i narzędzi osiągania celów. Jednocześnie ważne jest reagowanie na impulsy pochodzące z rynku oraz oczekiwania podmiotów podległych i mieszkańców. Jednym z kierunków rozwoju programowania rozwoju społeczno-gospodarczego jest odchodzenie od narzędzi twardych na rzecz czynników miękkich, wśród których ważne 
miejsce zajmuje partycypacja społeczna. Uczestnictwo społeczeństwa w procesach decyzyjnych, tworzeniu lub aktualizacji strategii rozwoju daje nowe możliwości kreowania efektywnego i zrównoważonego miasta, które jest dopasowane do potrzeb mieszkańców, dąży do dobrobytu i wysokiej jakości życia mieszkańców oraz rozwija się w sposób zróżnicowany, antycypując zmiany światowej koniunktury. Podejmowane działania stanowią kontynuację dążenia do uzyskania spójnego gospodarczo i społecznie miasta, silnego i dbającego o rozwój otoczenia ośrodka oraz podtrzymującego tradycyjne wartości i specjalizacje podmiotu. Nowe podejście skupia się na zagadnieniach dotyczących: sprawnego i partnerskiego zarządzania miastem, którego zwarta struktura zapobiegać ma tzw. rozlewaniu się; wypracowania wysokiej pozycji konkurencyjnej w drodze współpracy w trójkącie wiedzy, który tworzą badania, edukacja oraz innowacje (przemysł), oraz kreatywnego i proinnowacyjnego działania; współpracy z obszarem funkcjonalnym i wykorzystania najnowszych instrumentów wspierających realizację wskazanych celów.

\section{Literatura}

Bauman Z. [2000], Globalizacja. I co z tego dla ludzi wynika, Państwowy Instytut Wydawniczy, Warszawa.

Chojnicki Z., Czyż T. [1993], Region i regionalizacja w geografii [w:] Region, regionalizm - pojęcia i rzeczywistość, red. K. Handke, Slawistyczny Ośrodek Wydawniczy przy Instytucie Slawistyki PAN, Warszawa.

Dziemianowicz W. [2001], Globalizacja a regionalizm [w:] Globalizacja, red. J. Klich, Instytut Studiów Strategicznych, Kraków.

Europa 2020. Strategia na rzecz inteligentnego i zrównoważonego rozwoju sprzyjajacego właczeniu społeczneти [2010], Komisja Europejska, Bruksela, 3.03.2010, KOM(2010) 2020 wersja ostateczna.

Jewtuchowicz A. [2006], Terytorium, terytorializacja, rozwój regionalny [w:] Przedsiębiorczość i konkurencyjność a rozwój regionalny, red. A. Klasik, Prace Naukowe Akademii Ekonomicznej w Katowicach, Katowice.

Karta lipska na rzecz zrównoważonego rozwoju miast europejskich przyjęta z okazji nieformalnego spotkania ministrów w sprawie rozwoju miast i spójności terytorialnej w Lipsku, w dniach 24-25 maja 2007 r., www.sarp.org.pl/pliki/karta_lipska_pl.pdf (data dostępu: 14.10.2016).

Krajowa polityka miejska 2023 [2015], Dokument przyjęty uchwałą Rady Ministrów w dniu 20 października 2015 r., Ministerstwo Infrastruktury i Rozwoju, Warszawa, październik.

Lariusz N. [2013], Wprowadzenie do partycypacji społecznej w Polsce [w:] Partycypacja społeczna w Polsce. Atlas dobrych praktyk, red. M. Ćwiklicki, M. Frączek, Fundacja Gospodarki i Administracji Publicznej w Krakowie, Kraków.

Lubbe A. [2010], Globalizacja i regionalizacja we współczesnej gospodarce światowej [w:] Rozwój w dobie globalizacji, red. A. Bąkiewicz, U. Żuławska, PWE, Warszawa.

Miasta przyszłości. Wyzwania, wizje, perspektywy [2011], Komisja Europejska, Dyrekcja Generalna ds. Polityki Regionalnej, październik, http://ec.europa.eu/regional_policy/ 
sources/docgener/studies/pdf/citiesoftomorrow/citiesoftomorrow_final_pl.pdf (data dostępu: 14.10.2016).

Miejski wymiar polityki UE - kluczowe elementy agendy miejskiej UE [2014], Komunikat Komisji do Parlamentu Europejskiego, Rady, Europejskiego Komitetu Ekonomiczno-Społecznego i Komitetu Regionów, Komisja Europejska, Bruksela, dnia 18.07.2014, $\operatorname{COM}(2014) 490$ final.

Nowa karta ateńska 2003. Wizja miast XXI wieku [2003], Europejska Rada Urbanistów, Lizbona, 20 listopada.

Olech A., Kaźmierczak T. [2011], Modele partycypacji publicznej [w:] Partycypacja publiczna. O uczestnictwie obywateli w życiu wspólnoty lokalnej, red. A. Olech, Instytut Spraw Publicznych, Warszawa.

Oman C. [2002], Globalization, Regionalization, and Inequality [w:] Inequality, Globalization, and World Politics, eds A. Hurrell, N. Woods, Oxford University Press, New York.

Pakt amsterdamski podpisany [2016], https://urbnews.pl/pakt-amsterdamski-podpisany/ (data dostępu: 14.10.2016).

Pietrzyk I. [2009], Globalizacja i regionalizacja gospodarki światowej [w:] Gospodarka światowa $w$ warunkach globalizacji i regionalizacji rynków, red. S. Miklaszewski, E. Molendowski, Difin, Warszawa.

Putnam R. [1995], Demokracja w działaniu. Tradycje obywatelskie we współczesnych Włoszech, Znak, Fundacja im. Stefana Batorego, Kraków-Warszawa.

Rynio D. [2013], Kształtowanie nowej polityki regionalnej Polski w warunkach globalizacji $i$ integracji, Wydawnictwo Uniwersytetu Ekonomicznego we Wrocławiu, Wrocław. Tinbergen J. [1965], International Economic Integration, Elsevier Publishing, Amsterdam. Urban Agenda for the EU. Pact of Amsterdam [2016], http://urbanagendaforthe.eu/pactofamsterdam/ (data dostępu: 14.10.2016).

\section{Socio-economic City Strategy in New World Economy Conditions (Abstract)}

Given the current conditions of the worldwide economy, strategic city management is a complex activity, the essence of which is quick reaction to changing situations where the main processes of the world economy intersect. Cities face numerous challenges across many branches, but the most essential of them concern investment, innovation, creativity and competitiveness. Balanced development remains a general goal, but the structure and grading of detailed goals is changing for cities. The inhabitants of a city are involved in developing its strategy and the effect of its activity is city building fitted to inhabitants' needs and boosting their quality of life. The goal of the article is to indicate determinants of the world economy which ultimately determine changes in the strategic planning of cities' socio-economic development and their priorities. The research methods used include analysis of the literature, deduction, cognitive research and cause-and-effect analysis.

Keywords: city, participation, development strategy, globalisation, integration, regionalisation. 